\title{
THE CHILD WOMAN IN FIN-DE-SIÈCLE VIENNA
}

\author{
ANNAMÁRIA BIRÓ \\ Babeș-Bolyai University, Department of Hungarian Literary Studies \\ biro.annamaria@eme.ro
}

\begin{abstract}
The $20^{\text {th }}$ century witnessed an increasing interest in psychoanalysis and, in relation to it, sexual deviances. Vienna had an outstanding role in this interest because it was where Sigmund Freud worked, and where the psychoanalytic society formed by his disciples was also active. In his volume from 1905, entitled Drei Abhandlungen zur Sexualtheorie, he listed certain forms of child sexuality as sexual deviances. At the same time, the arts often represented the child body both in its innocence, but often also as a sexual object. I think that the publication of a novel which was perceived as belonging to the category of child pornography in Vienna in 1906 can also be seen as part of this process, although it has been discussed earlier independently from other cultural or scientific processes of the turn-of-the-century Vienna. My paper attempts to place this novel into the above detailed context.
\end{abstract}

Keywords: Fin-de-Siècle Vienna, child woman, child sexuality, Sigmund Freud, Felix Salten, psychoanalysis

As of March 2019, everybody can access the four-hour long, psychologically demanding documentary about the life of Michael Jackson entitled Leaving Neverland, based on the memories of the children living on his estate, presented at the 2019 edition of the Sundance Film Festival. The effects of the documentary are still unpredictable, and the first reactions to the film are mostly concerned with Michael Jackson the artist: the fans reject any accusation of paedophilia, while some channels and shows are no longer broadcasting any of his music. The response to the film is less concerned with the boys who have grown to be adults, and the comments on them are likely to stir more indignation than the film itself. Barbra Streisand said at the end of March that the children who had suffered sexual abuse did not suffer an irreversible psychological trauma, they are both happy adults with families, and even the time they spent in Neverland cannot be called a totally negative period of their lives.

To be sure, the sexual relationship between an adult and a child is an ancient issue, rarely represented openly by artists, and most often treated as a taboo, as a non-existent thing. As child sexuality itself, the discourse on it was typically also a matter of interdiction. Before the emergence of psychoanalysis in the late $19^{\text {th }}$, early $20^{\text {th }}$ century, the consensual opinion was that sexuality only appears with the onset of puberty, a child before that age is completely asexual, as their sexual 
organs are not yet developed. The change in this view was brought about by Sigmund Freud's 1905 Three Essays on the Theory of Sexuality, the second chapter of which discusses the sexuality of the child (S. Freud 1905). My paper mostly treats the figure of the child woman, whose innocent sexuality was inspiring for several artists of early $20^{\text {th }}$ century Vienna, resulting in child sexuality becoming not only one of the most important subjects of scientific discourse, but decisive also in terms of artistic representation. In our cultural space, the prototype of the sexually overheated child woman is clearly Lolita of Nabokov's novel, who has overshadowed her turn-of-the-century predecessors, Wedekind's Lulu, Schnitzler's and Wittels' Mizzi, or even Pepi, who will be repeatedly mentioned later on.

My starting point is a novel published in Vienna in 1906 which had a similarly subversive effect in the $20^{\text {th }}$ century as the 2019 documentary mentioned in the introduction. This is because it represents a side of sexuality which was well known to many, but which could not be a subject of public discourse. The novel goes beyond raising a social problem - it also offers reference points for the artistic and scientific representation of child sexuality. In the last days of the Monarchy, writers and artists tried to stretch the limits of the unutterable, they fought for the liberation of repressed sexuality, and the boundaries were flexible - artists were called to justice for not wanting, or not being able to make a difference between women's and children's sexual emancipation.

The pornographic novel entitled Josefine Mutzenbacher oder die Geschichte einer Wienerischen Dirne von ihr selbst erzählt was published anonymously in a private edition in 1906, in 1000 numbered copies. The Hungarian edition appeared in 2002 in the translation of Dezső Tandori, bearing multiple marks of a "dangerous reading": it was published in the 'tabu.erotica' series of the Publisher PolgArt, inscribed "Only for people aged 18 or over" written on the cover against a red background. The novel has had several English translations as well, including one in 2018 (Mutzenbacher 2018) which follows the chapter and paragraph division of the original German text, unlike the earlier translations. The story, narrated in the first person singular, is the sexual Bildungsroman or Josefine Mutzenbacher, alias Pepi, a little girl from the working-class area of Ottakring. The novel violates many taboos and becomes subversive in several respects. The text tells the story of the little girl from when she was 5 and until her puberty, the traditional starting point of sexual maturation. By that age, however, Pepi has already become acquainted with almost all possible forms of sexuality, she has been sexually involved with many children and adults: her brother, her playmates, then adult males - a roomer, the beer agent, the landlord's son, the priest, her teacher, and finally her father who, with his friend, force the girl to become a prostitute. However, these are just the words of the reader: there is no forcing at all in the novel, the child turns to all of her new experiences eagerly and curiously, she 
takes pleasure in all new forms of sexuality, and she perceives the time of her prostitution as a fairly pleasurable way of earning money, which at the same time offers her the possibility to escape her poverty. Pepi is by no means an exception in the novel, she is not an example of deviance, but an average suburban child. The text claims that children who are left alone by their busy parents get in touch with sexuality at an early age as they play mommy and daddy role plays, and then they want to try what they learnt with adults as well, who are not reluctant to do so. As the people who represent the different forms of authority (the teacher, the priest, the policeman or the father) also become members of the sexual network, there is no way back from this form of life, the narrator Pepi claims that it is just accident or some external force which decides who will get to live a traditional, normative life.

„Die Geschichte mit dem Katecheten ist aber für mein ganzes Leben entscheidend geworden, wie ich im weiteren Verlaufe der Begebenheiten zeigen werde. Denn trotz dieser Kindergeschichten wäre ich vielleicht eine brave Frau geworden, wie Melanie es wurde, die heute mit einer Schaar von Kindern im Gasthaus ihres Vaters sitzt, oder wie manche andere von meinen damaligen Genossinnen, denen diese frühzeitigen Ausschreitungen nichts geschadet haben." (Mutzenbacher 1906: 232) ${ }^{1}$

Although the novel could be read as social criticism, the text actually distances itself from such a reading and functions primarily as pornography without any moral or social message. It was repeatedly published during the $20^{\text {th }}$ century in many copies, and although it mostly circulated underground, by the end of the century became part of the Austrian cultural memory. The digitized version of the first edition is on the website of the Austrian National Library, ${ }^{2}$ the locations of Pepi's life in Vienna can be visited on a tour named after Josefine Mutzenbacher, ${ }^{3}$ the text has been analysed in a great number of studies, volumes, monographs, ${ }^{4}$ and Austrian literary works also make frequent reference to this book. In 2006, at the centenary of the first edition, the cabaret Bambi, Josefine \& Co directed by Elisabeth Joe Harriet was on show for a long time, the famous Austrian author Franzobel published a novel in 2002 entitled Scala Santa oder Josefine Mutzenbachers Höhepunkt, and the 2008 novel of J. J. Preyer merged crime literature with pornography in Ermittlungen im Falle Mutzenbacher. Kriminalroman.

The consensus today is that the anonymously published text was written by Felix Salten. Salten (1869-1945) was born into an impoverished Jewish family, and although he had to find a job at a young age, he soon had a flourishing carrier: in 1894 he became editor and theatre critic of the Wiener Allgemeine Zeitung, published political writings under a pseudonym in Zeit, and established his fame as a committed Zionist. In his text published in 1925, Neue Menschen auf alter Erde. Eine Palästinafahrt he used the term new man, well known in German activism, as a category of the citizens of the future state to be formed on the 
Holy Land. Still, his best known novel is Bambi. Eine Lebensgeschichte aus dem Walde, written in 1923 about a roe deer fawn, translated into numerous languages, and nowadays considered to be part of children's literature. The astonishing effect of Salten's authorship is probably due precisely to the fact that the text that represents sexuality without taboos and the story of the fawn which often makes children cry are authored by the same person. However, the subtitle of the Bambi, A life in the woods, similarly to Mutzenbacher's, also refers to the same intention: the story of the little fawn and his friends should be taken seriously, read as a life history, and in this sense his childhood is a story of initiation. Bambi is just as eager to know the world surrounding him, the rules and the animals living in the forest, as Pepi is to know the world of the suburbs. ${ }^{5}$ While the world celebrated the premiere of the animated film in 1942, Salten was prohibited in Germany, and his works were listed as degenerate art. Not so much because of pornography of course, but rather because of his Jewish origin.

Coming back to the fin de siècle: Salten's entourage in Vienna should also be taken into account. Beginning with 1890 he becomes a regular guest of the Griensteidl café, where he befriends the members of the Jung-Wien movement, Arthur Schnitzler, Hugo von Hofmannsthal, Hermann Bahr and Karl Kraus, although his relationship with the latter wasn't quite friendly. He had a closest relationship with Arthur Schnitzler, who was indeed considered for a long time the author of the Mutzenbacher book, mainly because of his scandalous drama Reigen, or Fraulein Else. Schnitzler mentions this in his diary as well, in an entry on 10 April 1911, when, because of a note in a lexicon of pseudonyms which lists his name or Salten as the author of the Mutzenbacher novel, he mentions within brackets that the author is Salten, and not himself. ${ }^{6}$ There is no further or more accurate information about the authorship, but it seems that Austrian philological research takes this for granted.

In my view Josefine Mutzenbacher's story can be located within two interdependent structures, which, on the one hand, may explain why pornographic literature turned towards child sexuality, while on the other hand the text can thus be treated as a part of a larger whole, and not just as a subversive pornographic text, as it is often the case. The first structure is the social and cultural life of the turn-of-the-century Vienna and its literary representations, the other is the psychoanalytic discourse of the age which incorporated sexuality.

If we locate the text in the environment of early $20^{\text {th }}$ century Vienna, we must accept that the book may have several references to reality, even if many elements of the plot were considered taboo later, or even at the time of publication. The space of the city, the life conditions in the suburbs, the structure of the families, the representation of poverty and lack of housing were most probably very close to reality. At the beginning of the $20^{\text {th }}$ century, the population of Vienna reached 2 million, but this demographic boom had already started in the mid- $19^{\text {th }}$ 
century, causing a parallel increase in housing problems. For example, between 1830 and 1850 the number of inhabitants increased by $40 \%$, but the capacity of housing facilities only increased by $10 \%$. (Maderthaner-Musner 1999.) Children in suburban families usually slept in the same room with the adults, and the parent-child relationship was influenced also by the practice of boarding: several of the bedrooms were occupied not by family members, but strangers in the capacity of tenant. This way sexuality had no intimacy: it happened before the eyes, or at least ears of the children, as is proven by the case of Pepi and her family. It has been repeatedly pointed out that the building of the ring roads fostered spatial segregation and it was a spatial construction of power and subordination, even if it wasn't left out of the modernisation process: the public transportation network and the school system can be seen as achievements of the social democrats. All these social results are clearly visible in the novel, as well: the suburban children go to school and religion classes, are trained in various ways, and their livelihood is also ensured as long as the parents - or at least one of the parents - has a job. Vienna in that age, as is also shown by the text, had an extensive prostitution network, and child prostitution was not rare, either. The vertical spatial structure represented by Stefan Zweig also appears in the novel. Zweig describes prostitution as a hidden force, and divides the space into visible and invisible parts, suggesting that open sexuality was only at home on the lower levels, in closed brothels and invisible places.

„But, generally speaking, prostitution was still the foundation of erotic life outside of marriage; in a certain sense it constituted a dark underground vault over which rose the gorgeous structure of middle-class society with its faultless, radiant façade." (S. Zweig 1943: 72)

While Zweig's text suggests that prostitution only thrived in spaces hidden from middle-class eyes and dark underground basements, the vertical structure of the space in Josefine Mutzenbacher's story proves that the very same kind of illegal sexual games took place on all levels of the construct: the basement is the meeting place of the 8 years old Pepi and the adult beer agent Horak, the attic is the place of the sexual encounter between the child Ferdl and the adult Mrs Reinthaler, and the apartments on all the floors are also the locations of all kinds of couples, threesomes, foursomes, children, adults, legal and illegal sexual acts. Prostituted Pepi does not hide in basements, either: she waits for her clients on staircase landings, in cheap rooms or even studios. The middle-class gaze could only avoid the omnipresent thriving of sexuality if it really wanted to: Josefine Mutzenbacher turned even open spaces into sexual playgrounds. The subversive character of the novel is perhaps not even due to the representation of sexuality without taboos, but mainly to the fact that the protagonist is an immature child woman, who first experiences sexuality with other immature children. However, even in this respect, the text is not without its antecedents in contemporary 
Vienna. As I mentioned before, Freud's essay on children's sexuality was published just one year earlier, and the representation of a child's body was a concern not only of writers, but also of artists. At the turn of the century, Gustav Klimt, Oskar Kokoschka, Anton Kolig, or somewhat later Egon Schiele experimented with various forms of representation of a naked boy's body, and the naked representation of pre-pubescent children's bodies was also not uncommon in the age. Oskar Kokoschka was among the first to paint nude children, and often represented his lover, Alma Mahler, as a virgin. They painted not only the sexual act, but even masturbation as an artistic object to avert the ban on representing sexuality. ${ }^{7}$ The paradox of the perversion of the innocent, virgin body was a matter of interest for artists, while they considered that sexual games with children were part of normality. However, societal trends and criminal law did not always agree. For instance, Egon Schiele was repeatedly summoned to court, at first only because of the representation of a nude child's body. However, in order for the authorities to deal more seriously with the relationship of Egon Schiele and his child models, it wasn't enough that everybody at his place of residence at the time, Neulengbach, knew about the unorthodox way of life of Schiele and his mistress, Wally Neuzil, and that the children were not only models for Schiele, but also had access to the completed works of art. Schiele claimed that the children were familiar with various forms of sexuality, so he didn't pervert them. Interestingly enough, the only case that the authorities treated as a possible instance of abuse was that of Tatjana von Mossig, although nothing could be proved to have happened between her and Schiele in the artist's house. Nevertheless, it needed a child of a higher social status to speak of sexual abuse, while in case of low status children the authorities were indulgent about the artist using them as models.

A somewhat later case, but one which has also caused sensation recently was Adolf Loos's court trial on charges of paedophilia in 1928, according to which between 28 August and 3 September the famed architect, aged 57 at the time, had lured Marie F., aged 9, Erika P., aged 8 and Ida F. aged 10 to his house with the pretext of posing as his models, and used them for oral sex. During the trial several earlier cases involving Loos were also revealed - instances when the artist helped child women with money in the Prater, paid for them to ride the Giant Wheel, and they often posed as models for him.

The name for young, but sexually mature girls in literary texts was most often süßes Mädel (sweet maiden) (following Arthur Schnitzler) - typically coming from the suburbs, uneducated, but with an irresistible sexual appeal. The men who got involved in sexual relations with these girls were known in the suburbs as Hendlbucker. The literary prototype of the child woman originated not much later than Josefine Mutzenbacher: the first writing using this title, Das Kindweib, was published in 1907, under the psyeudonym Avicenna, in Karl Kraus's magazine Die Fackel (Wittels 1907). The author was Fritz Wittels, one of Freud's first 
disciples, ${ }^{8}$ so he read his text to Sigmund Freud himself before it was published, then later presented it to the psychoanalytic association, and only afterwards published it in his good friend's magazine. ${ }^{9}$ Wittels had two main inspirations for writing his work. One was of course Freud's Drei Abhandlungen, which was received with quite a lot of confusion and rejection. However, Wittels claimed that Freud's disciples knew right after it was published that this text was to change fundamentally the way in which people thought about sexuality (Edward Timms [ed.] 1996). The other motivation was a real child woman, Irma Karczewska, who became first Karl Kraus's lover, and later Wittels's own lover as well, creating a strange ménage à trois. ${ }^{10}$ Irma came from a working class suburb and in 1905 the 15-year-old girl played in Frank Wedekind's Die Büchse der Pandora, in which she fascinated Kraus, who could not escape her charms for a long time to come. Wittels got acquainted with Irma whenn she was 17. In his later memoirs he was to call her a silly, whimsical and headstrong girl who drank too much alcohol, but whose sexual appeal was stronger than anything (Edward Timms (ed.) 1996: 77). ${ }^{11}$ Some 30 years after Das Kindweib, Wittels published another text about the subject, which can be regarded as a summation of the fashion of interest in the child woman. The title is Kindweib, die große Mode (Wittels 1930: 133-156). Here he describes the child woman-hetaera of the turn of the century: a primadonna, a woman with narcissistic inclination who, giving up motherhood, wants to play the eternal child (Wittels 1930: 135). The rest of the description is very similar to the representation of today's Japanese manga-schoolgirls:

„Gekleidet gehen die Frauen wie Kinder, mit unbedeckten Knien, kurzen Haaren, möglichst zartem Teint, mit dem runden einladenden Mund des Babys und großen erstaunten Augen, die man künstlich noch größer und erstaunter blicken lässt, als wäre man an dieser Welt interessiert wie ein Schulmädchen.“ (Wittels 1930: 135.)

Salten's description of seven-year-old Pepi is similar to this (Mutzenbacher 1906: 15.) Not just this description, but Wittels's remark that a child woman can get pleasure from any man whatsoever is also valid for Pepi; what is more, since she was born with every perversion - and this is a Freudian idea - homosexuality is also not something strange to her. Both in the case of Wittels's Kindweib and Josefine Mutzenbacher, the female body can sexually arouse and satisfy the female protagonist. Sexuality is always sharply distinguished from feelings, therefore the simultaneous presence of several partners causes no emotional distress. According to Wittels, the society that follows middle-class morals stigmatises the child woman, sees her as a prostitute, which leads to early psychological trauma and in most cases to alcoholism, which, together with sexually transmitted diseases, often cause the premature death of these creatures from a different world. While in 1907 Wittels considered that the sexually precocious child woman was the female counterpart of the male genius, by 1930 he increasingly regarded them 
as weak and wasted creatures struck by sexually transmitted diseases, who underpin Freud's theories that the cause of hysteria and auto-eroticism is early sexuality. In contrast, Josefine Mutzenbacher does not die young, she spends her last days in a renowned sanatorium and looks back on her life with satisfaction and even pride:

"Aus Armut und Elend wie ich entstammt bin, habe ich alles meinem Körper zu verdanken. Ohne diesen gierigen, zu jeder Sinnenlust frühzeitig entzündeten, in jedem Laster von Kindheit auf geübten Körper, wäre ich verkommen, wie meine Gespielinnen, die in Findelhaus starben, oder als abgerackerte, stumpfsinnige Proletarierfrauen zu Grunde gingen. Ich bin nicht im Dreck der Vororte erstickt. Ich habe mir eine schöne Bildung erworben, die ich nur einzig und allein der Hurerei verdanke, denn diese war es, die mich in Verkehr mit vornehmen und gelehrten Männern brachte. Ich habe mich aufklären lassen und gefunden, daß wir armen, niedrig geborenen Weiber nicht so viel Schuld haben, als man uns einreden möchte. Ich habe die Welt gesehen und meinen Geschichtskreis erweitert, und alles das verdanke ich meinem Lebenswandel, den man einen »lasterhaften « nennt." (Mutzenbacher 1906: 1-2.)

In this sense the story of Josefine Mutzenbacher shouldn't necessarily be read as social criticism or the criticism of power structures, but much rather as a refutation of deviant sexuality generated by the scientific discourse on sexuality. The girl's many, often painful sexual experiences should make the reader horrified, but the girl recounts these experiences with such natural ease which suggests that we should not see it as deviant, but as an everyday life experience of certain social classes. What's more, the relationship of the landlord's son and his nurse may prove that there are no social barriers either, the same thing happens behind every closed door. ${ }^{12}$

The publication of Freud's Drei Abhandlungen zur Sexualtheorie in 1905 wasn't at all as unexpected as Freud and his disciples often claimed. Wilhelm Stekel had already dealt with child sexuality in the 1890s, and the later study of Albert Moll, Das Sexualleben des Kindes, published in 1909, was also a summary of previous research. At the same time, Josefine Mutzenbacher's life experiences seem to be not only an answer to Freud's and Moll's theory of child sexuality, but also a refutation of Otto Weininger's 1909 Geschlecht und Charakter, translated into English as Sex and Character. Weininger wrote his successful book in reaction to women's emancipation ambitions, in which he sentenced women to continuing passivity by claiming that a superior life was the sole prerogative of men.

Comparing Freud's scientific work on child sexuality with the story of Josefine Mutzenbacher, one can find several parallels. Freud divides the first part of the psychosexual development of the child (from a few months to 5-6 years) into three stages (oral, anal, phallic), then emphasizes the importance of the Oedipal stage in the birth of the super ego. He considers the next stage, from 5-6 to 
puberty, the stage of latent sexuality, and the period of puberty the stage when the libido focuses on the right object. In Pepi's case it is the second period, the latent stage, which happens differently, meaning that it is characterized not by repression, but by liberation. Actually, Freud himself recognizes that this change is also scientifically grounded, saying that in the second part of childhood (from the age of 8 years to puberty) anything can happen. The genital areas during these years already behave as they do in adulthood, experiencing excitement and readiness, as other erogenous zones experience any kind of sexual pleasure. (Freud 1905: 85.) The sexual curiosity typical of Pepi, her interest in sexuality which turned her into a prostitute took place because the latent stage was missing from her childhood. What reads as pornographic text int he novel, appears as follows in scientific discourse:

"It is instructive to know that under the influence of seduction the child may become polymorphous-perverse and may be misled into all sorts of transgressions. This goes to show that it carries along the adaptation for them in its disposition. The formation of such perversions meets but slight resistance because the psychic dams against sexual transgressions, such as shame, loathing and morality - which depend on the age of the child - are not yet erected or are only in the process of formation. In this respect the child perhaps does not behave differently from the average uncultured woman in whom the same polymorphous-perverse disposition exists.

The same polymorphous or infantile disposition fits the prostitute for her professional activity, and in the enormous number of prostitutes and of women to whom we must attribute an adaptation for prostitution, even if they do not follow this calling, it is absolutely impossible not to recognize in their uniform disposition for all perversions the universal and primitive human." (Freud 1962: 50.)

Freud also considers it a form of sexual perversion if someone's sexual object is the child, and he thinks that this is alarmingly frequent in case of teachers and servants, just because they have the most opportunity for it. This way Pepi's sexual relationship with the teacher, the priest, the nurse, or other unemployed adults living in their house is not a unique case, but a general problem documented by scientific discourse. Similar parallels can be drawn between Pepi's behaviour and Georg Simmel's 1909 work, the Psychologie der Koketterie (The Psychology of Coquetry): in Simmel's view, what Pepi does by instinct, almost unconsciously, is in fact the imitation of a conscious and well outlined behavioural pattern.

„Denn dieser ist es eigen, durch Abwechslung oder Gleichzeitigkeit von Entgegenkommen und Versagen, durch symbolisches, angedeutetes, »wie aus der Ferne« wirksames Ja- und Neinsagen, durch Geben und Nichtgeben oder, plato- 
nisch zu reden, von Haben und Nichthaben, die sie gegeneinander spannt, indem sie sie doch wie mit einem Schlage fühlen lässt - es ist ihr eigen, durch diese einzigartige Antithese und Synthese Gefallen und Begehren zu wecken.

In dem Verhalten der Kokette fühlt der Mann das Nebeneinander und Ineinander von Gewinnen- und Nicht-gewinnen-Können, das das Wesen des »Preises « ist, und das ihm mit jener Drehung, die den Wert zum Epigonen des Preises macht, diesen Gewinn als wertvoll und begehrenswert erscheinen lässt." (Simmel 1909)

In Simmel's views a man must never resist a woman's temptation, which also explains Pepi's indignation when a fit young man does not react to her seduction (until he gives a rational explanation for it). Michel Foucault states that the artificial scientific discourse masks true sexuality (Foucault 1979). The strange experiment - to say the truth about sexuality - has always been in the background, this was the real background, which made possible the misinterpretations, the digressions and escapes, the unfolding of the consequences of this process.

The pornographic novel Josefine Mutzenbacher appeared in a period when the discourse on child sexuality gained ground: the previously tabooed problem was treated with increasing interest in the arts and in literature, as well as by science. We do not have much information on the audience of this novel, but based on the person of the author it might not be farfetched to say that it was probably the educated, art-loving audience of Vienna at the turn of the century. I might even venture to say that we are dealing with different forms of appearance of the same subject, and these texts should be discussed in their relation to each other/ as inter-related.

\section{References}

Michel Foucault, The history of sexuality, translated by Robert Hurley (London: Penguin, 19791991)

Sigmund Freud, Drei Abhandlungen zur Sexualtheorie (Wien, 1905)

Sigmund Freud, Three Essays on the Theory of Sexuality (New York: Basic Books, 1962) https:// www.globalgreyebooks.com/content/books/ebooks/three-essays-on-the-theory-of-sexuality. pdf

Huszár Ágnes, „Világunk: Bambiland”, Múlt és Jövő (2012): 107-111.

Claudia Liebrand-Franziska Schößler, "Fragmente einer Sprache der Pornografie: Die 'Klassiker' Memoirs of a Woman of Pleasure (Fanny Hill) und Josefine Mutzenbacher", in Freiburger FrauenStudien 15 (2004): 107-129.

Wolfgang Maderthaner-Lutz Musner, Die Anarchie der Vorstadt: das andere Wien um 1900 (Frankfurt, New York: Campus, 1999)

Josefine Mutzenbacher oder Die Geschichte einer wienerischen Dirne von ihr selbst erzählt (Wien: Privatdruck, 1906)

Josefine Mutzenbacher, Egy kis bécsi kurva emlékezései, transl. by Tandori Dezső (Budapest: PolgArt kiadó, 2002) 
Josefine Mutzenbacher or The Story of a Viennese Wench, as Told by Herself, translated by Ilona J. Hämäläinen-Bauer (Helsinki: Books on Demand, 2018)

Claudia Öhlschläger-Dietmar Schmidt, „,Weibsfauna'. Zur Koinzidenz von Tiergeschichte und Pornographie am Beispiel von Bambi und Josefine Mutzenbacher", in Hofmannsthal Jahrbuch 2, 1994, 237-286.

Clemens Ruthner, "The Back Side of Fin-de Siècle Vienna: The Infamously Infantile Sexuality of Josefine Mutzenbacher," in Contested Passions: Sexuality, Eroticism and Gender in Modern Austrian Literature and Culture, ed. Clemens Ruthner, Raleigh Whitinger (New York: Peter Lang, 2011), 91-104.

Arthur Schnitzler, Tagebuch 1909-1912, Ed. Werner Welzig et al. (Vienna: Verlag der ÖAW, 1981).

Georg Simmel, „Psychologie der Koketterie”, Der Tag (1909), Nr. 344, 347, 1-3, 1-3, http://socio. $\mathrm{ch} / \mathrm{sim} /$ verschiedenes/1909/koketterie.htm

Edward Timms (ed.), Freud and the Child Woman. The Memoirs of Fritz Wittels, (New Haven: Yale University Press, 1996)

Volker Hage, „Pornograpie kann Kunst sein: 'Josefine Mutzenbacher’”, in Schriftsteller vor Gericht: Verfolgte Literatur in vier Jahrhunderten, ed. Jörg-Dieter Kogel (Frankfurt/M.: Suhrkamp, 1996), 281-92.

Fritz Wittels, „Das Kindweib”, Die Fackel, (1907): 14-33.

Fritz Wittels, Sigmund Freud; Der Mann, die Lehre, die Schule (Wien, Leipzig, Zürich: 1924)

Fritz Wittels, „Kindweib, die große Mode”, in A. J. Storfer, (Hrsg.), Almanach der Psychoanalyse (Wien: Internationaler Psychoanalytischer Verlag, 1930), 133-156.

Stefan Zweig, The World of Yesterday (London: Cassell and Company, 1943).

\section{Notes}

1 The novel claims that girls' sexual maturation results in the repression of early sexuality, as most girls give up further experimenting for fear of pregnancy.

2 http://digital.onb.ac.at/RepViewer/viewer.faces?doc=DTL_5132343\&order=1\&view=SINGLE

3 http://www.wienfuehrung.com/Mutzenbacher.html

4 The most important of these are: Ruthner 2011; Öhlschläger-Schmidt 1994; Volker 1996; Liebrand-Schößler 2006.

5 Writing about Elfriede Jelinek's book Bambiland, Ágnes Huszár points out that Salten's Bambi is not a nice little children's story that one can easily identify with. It is the Walt Disney animated film of 1942 which turned it into a false, kitschy tale, because it lacks the metaphysical figure of Evil. (Huszár 2012)

6 „Frage wegen einer Bemerkung im Lexicon der Pseudonyme, wo bei einem pornographischen Buch 'Josefine Mutzenbacher' als mögliche Autoren ich und Salten mit Fragezeichen genannt sind. (Wohl Salten)”. (Ruthner 2011: 91-104, Schnitzler 233.)

7 The Unteres Belvedere gallery organized an exhibition entitled Klimt/Schiele/Kokoschka und die Frauen between October 2015 and February 2016 with the purpose of a summary presentation of these trends.

8 And also the author of Freud's first biography (Fritz Wittels 1924).

9 Wittels' relationship with both Freud and Karl Kraus had deteriorated. His memoirs, which he wrote later in America, in English, revealed the causes of this deterioration. Because the whole text has a self-explaining tone, I only use this argumentation with considerable criticism, and always note when I use Wittel's opinions (Edward Timms [ed.] 1996). 
10 The excitement over sharing women appears in the Josefine Mutzelbachel novel as well. Felix Salten also experienced such a three-sided relationship when for a while he shared the actress Adele Sandrock with his friend Arthur Schnitzler.

11 It is not the subject of this paper, but it is interesting to note that Kraus and Wittels's breakup was also treated in literary texts. Karl Kraus in the Persönliches column of Die Fackel published 36 aphorisms about Wittels in 1908, in which he calls his earlier friend his vassal and his echo. In turn, Wittels uses Kraus in his novel Ezechiel der Zugereiste in the character of Benjamin Eckelhaft, while Irma appears in the novel with the usual name of child women, as Mizerl.

12 "Mir fiel es gar nicht ein, daß man in so einem herrlichen Zimmer auch solche Dinge machen könne, wie das, was wir gestern im Keller getan hatten." - wonders Pepi after the events with the landlord's son. (Mutzenbacher 1906: 122.) 